\title{
Impact of Heat Treatment on the Freezing Points of Cow and Goat Milk
}

\author{
Bohumíra Janštová, Pavlína Navrátilová, Michaela Dračková, Hana Přidalová, \\ Lenka Vorlová
}

Department of Milk Hygiene and Technology, Faculty of Veterinary Hygiene and Ecology, University of Veterinary and Pharmaceutical Sciences, Brno, Czech Republic

\author{
Received October 8, 2008 \\ Accepted April 6, 2009
}

\begin{abstract}
The aim of this study was to monitor the impact of heat treatment variables on the freezing point of cow and goat milk.

The freezing point (FP) was established in 30 bulk tank samples of goat milk and in 30 bulk tank samples of cow milk which were subject to laboratory heat treatment at temperatures of $72{ }^{\circ} \mathrm{C}(\mathrm{A}), 85^{\circ} \mathrm{C}(\mathrm{B}), 95^{\circ} \mathrm{C}(\mathrm{C})$, with the same exposition times of $20 \mathrm{~s}$.

Freezing point measurements of raw and heat-treated milk were carried out in compliance with the Standard CTS 570538 by a thermistor cryoscope.

The FP of raw cow milk increased with heat treatment from the initial values of $-0.5252 \pm$ $0.0114{ }^{\circ} \mathrm{C}(\mathrm{O})$ by $0.0023{ }^{\circ} \mathrm{C}(\mathrm{A}), 0.0034{ }^{\circ} \mathrm{C}(\mathrm{B})$ and $0.0051^{\circ} \mathrm{C}(\mathrm{C})$. Changes in FP values of goat milk were detected, from its initial value of $-0.5530 \pm 0.0086^{\circ} \mathrm{C}$ there was an increase in the FP depending on the mode of heat treatment due to pasteurization by an average of $0.0028^{\circ} \mathrm{C}$ (A), $0.0036{ }^{\circ} \mathrm{C}(\mathrm{B})$ and $0.0054{ }^{\circ} \mathrm{C}(\mathrm{C})$.

The dynamics of the changes were similar both in goat and cow milk.

Freezing point values in cow and goat milk differed $(P \leq 0.01)$ when compared to the freezing point of untreated milk after the individual interventions as well as when compared between each other. An increase in the heat treatment temperature of cow and goat milk causes an increase in the freezing point (a shift towards zero). These results can be used in practice for checking the raw material in dairy industry.
\end{abstract}

Cryoscopy, temperature, goats, cows, pasteurization

Quality assurance and product safety are among the priorities of advanced market economies and the producers' obligations. The freezing point of milk is an important indicator of milk quality. The freezing point (FP) of milk is determined primarily to prove milk adulteration with water and/or to determine the amount of water added (Bhandari and Singh 2003). Studies in recent years have shown that undesirable dilution of milk with water is not the only cause of increase in the freezing point.

Raw cows' milk freezing point, being one of the quality indices of purchased milk, has been checked regularly in central laboratories in the Czech Republic since 1993 as an indicator of milk adulteration with extraneous water added on purpose or by way of process. Nowadays, the EU legislation does not decree FP monitoring of consumer heat-treated milk (Decree 203/2003 Coll., Decree 638/2004 Coll. In: Navrátilová et al. 2006). Nevertheless, the freezing point remains a quality index of raw cows' milk in the Czech Republic (accepted limit value in cow milk FP is $-0.520^{\circ} \mathrm{C}$ ). As for goat milk, the limit value for FP has not been established and its measurement is not done during milk analysis.

Freezing point is one of key properties of milk. Of the major milk constituents, lactose and also chlorides jointly make up 75 to $80 \%$ of freezing point value and play the most important role in the so-called freezing point depression of milk, the remaining $20-25 \%$ of the freezing point value are affected by other milk constituents: calcium, magnesium, lactates, phosphates, citrates, urea, etc. (Fox and McSweeney 1998). Fatty globules, casein micelles and whey proteins have a negligible effect on the milk freezing point

Address for correspondence:

Doc. MVDr. Bohumíra Janštová, Ph.D.

Department of Milk Hygiene and Technology

Faculty of Veterinary Hygiene and Ecology, University of Veterinary Sciences

Palackého 1/3, 61242 Brno, Czech Republic
Phone: +420541712

Fax: +420 541711

E-mail: janstovab@vfu.cz

http://www.vfu.cz/acta-vet/actavet.htm 
depression (Bhandari and Singh 2003). Kessler (1984) noted that milk fat had no effect on the freezing point of milk and that milk proteins affect it only very little: $2.66 \%$ of casein may decrease the freezing point by $0.000001{ }^{\circ} \mathrm{C}$, and $0.67 \%$ of whey proteins by $0.000407^{\circ} \mathrm{C}$.

In the past, it was assumed that milk dilution with water was the principal cause for increase in the freezing point. It has, however, been demonstrated that $1 \%$ of added water will cause an increase in the freezing point of milk by $0.006{ }^{\circ} \mathrm{C}$ (Singhal et al. 1977). The following internationally accepted interpretations of freezing point depression have been adopted: When the freezing point is lower than $-0.535^{\circ} \mathrm{C}$, milk is assumed free from added water; freezing point values between -0.530 and $-0.534{ }^{\circ} \mathrm{C}$ indicate that milk production checks are needed; freezing point range from -0.525 to $-0.529^{\circ} \mathrm{C}$ indicates a strong probability of the presence of extraneous water. When the freezing point was $-0.525^{\circ} \mathrm{C}$ or higher, the farmer was asked to prove that no water had been added to the milk (Singhal et al. 1997). Milk with the freezing point of $\leq 0.525{ }^{\circ} \mathrm{C}$ is considered free from added water (Fox and McSweeney 1998).

The FP of cow milk ranges usually in the interval of -0.520 to $-0.540{ }^{\circ} \mathrm{C}$. When compared to cow milk FP, goat milk FP is lower. For instance, Szijarto and van de Voort (1983) reported the value of $-0.5527^{\circ} \mathrm{C}$, whereas Janštová et al. (2007) detected the values in the course of lactation in the range of -0.5454 to $-0.5567^{\circ} \mathrm{C}$. Variation in the FP levels in cow and goat milk is due to a higher content of non-fat solids in goat milk (Alichanidis and Polychroniadou 1995).

The freezing point of milk is determined by the proportion of milk constituents in a true solution. Their content in milk is affected by a number of factors: breed, stage and order of lactation, occurrences of subclinical mastitis, nutritional deficiencies, water intake, weather conditions, thermal stress, seasonal influences, and presence of $\mathrm{CO}_{2}$ in milk (Rohm et al. 1991; Wiedemann et al. 1993; Antunac et al. 2001; Slaghuis 2001). FP levels vary also in goats from various regions (Espie and Mullan 1990).

Water content has a big impact on the FP(Szijarto and van de Voort 1983). Adulteration with water can be wilful or it can be caused by negligence, especially by technological imperfections in the primary production. In these situations, residual and condensed water passes into the milk (Buchberger 1966; Zee et al. 1982).

The following influences can come in action: milk adulteration with e.g. residual water, loss of salts due to e.g., formation of milk stone deposits, changes in milk acidity due to e.g., formation of lactic acid while fermenting lactose and gas content in milk (Kessler 1984). During the production, handling and processing of milk, small quantities of water may adulterate milk. This may result from washing and sterilising procedures or from careless practices.

In dairies, adulteration sources can also be lorry tanks, centrifuges, heat treatment devices, pipelines, and gauges. It was proved that a square meter of the surface area of these devices dilutes the milk with $40 \mathrm{ml}$ of combined water (Pal'o et al. 1992).

The FP of heat-treated milk depends on the FP level of raw milk and on the changes of the milk FP in the process of heat treatment. The FP is affected with heat treatment of milk depending on its thermal and temporal variables. Heat treatment causes an increase of the FP of pasteurized milk ranging from 0.001 to $0.009{ }^{\circ} \mathrm{C}$ as opposed to the FP levels of raw milk (Kessler 1984; Singhal et al. 1997).

FPvalues of heat-treated milk are usually higher than the FPvalue that is generally accepted as the quality criterion for raw cow milk: $-0.520^{\circ} \mathrm{C}$ (Coni et al. 1997); Navrátilová et al. (2006) established the FP of consumer heat-treated cow milk to be $-0.515{ }^{\circ} \mathrm{C}$.

The effect of the UHT (ultra high temperature treatment) depended on the technology used (direct or indirect UHT heating). Compared to raw milk, direct UHT heating caused a rise of the FP by $0.009{ }^{\circ} \mathrm{C}$, while indirect heating by $0.003{ }^{\circ} \mathrm{C}$. Singhal et al. (1997) 
reported an even greater increase of the milk FP after pasteurization and UHT treatment $\left(0.006-0.009{ }^{\circ} \mathrm{C}\right.$, and $0.023{ }^{\circ} \mathrm{C}$, respectively).

The objective of this project was to monitor FP changes in goat and cow milk due to various temperature and time variables and to compare the FP changes in heat-treated goat and cow milk.

The monitoring of impacts of heating variables on the FP of thermally treated milk, or establishing the FP to assess the technological yield in cheese production, product-drying operations or in production of fermented milk products may be of benefit to the dairy industry.

\section{Materials and Methods}

Samples of cow milk $(n=30)$ were acquired from a farm with 85 dairy cows in their $1^{\text {st }}$ to $3^{\text {rd }}$ lactation, crossbreeds of the Holstein and Czech Pied cattle. Average milk yield was 7,300 1/year. Daily feed ration was made of silage $(25 \mathrm{~kg})$, haylage $(8-10 \mathrm{~kg})$, spent grains $(8 \mathrm{~kg})$, hay $(1-2 \mathrm{~kg})$, cereals $(10 \mathrm{~kg})$ and an addition of straw and whey.

Samples of goat milk $(n=30)$ were acquired from a farm in Southern Moravian Region of the Czech Republic. The farm has 75 goats of the White Shorthaired breed in their $1^{\text {st }}$ to $8^{\text {th }}$ lactation, with an average milk yield of 2-3 1/day, 600-800 1/year. In the period between May to the beginning of November, the goats were fed a feed ration including pasture, $0.5 \mathrm{~kg}$ of hay and up to $1 \mathrm{~kg}$ of cereals (barley, triticale, oats), a mineral mixture with vitamins and salt, in the remaining period it was the winter feed ration: $3 \mathrm{~kg}$ of grass haylage, $1 \mathrm{~kg}$ of sugar-beet silage, $1 \mathrm{~kg}$ of hay and do $1 \mathrm{~kg}$ cereals, mineral mixture with vitamins and salt.

Cows and goats were milked twice a day. After milking, the milk was cooled to the temperature of 4-6 ${ }^{\circ} \mathrm{C}$ and kept at this temperature for a period of 12-24 h. Samples were collected in the period of April-August 2007. A total of 30 samples of raw goat and 30 samples of cow milk were collected. The samples, cooled o $4-6^{\circ} \mathrm{C}$, were transported in a way to prevent an increase of their temperature over $8^{\circ} \mathrm{C}$. They were not conserved and were pasteurized after delivery to the laboratory.

The laboratory heat treatment was carried out using stationary pasteurization at the following temperatures: $72{ }^{\circ} \mathrm{C}(\mathrm{A}), 85^{\circ} \mathrm{C}(\mathrm{B}), 95^{\circ} \mathrm{C}(\mathrm{C})$. Exposition times were identical at all temperatures, namely $20 \mathrm{~s}$.

The freezing point of milk was determined in raw goat and cow milk $(\mathrm{O})$ and milk was treated with heating (A, B , C) in compliance with the standard CSN 570538 (1998) using the Cryostar Funke Gerber Automatic 7160 thermistor cryoscope (Funke Gerber, Germany). The thermistor cryoscope was regularly calibrated on the day of measurements using standard solutions with the freezing points at $-0.408{ }^{\circ} \mathrm{C}$ and $-0.600{ }^{\circ} \mathrm{C}$ and the calibration was verified with the reference solution Lactrol $\left(-0.512{ }^{\circ} \mathrm{C}\right)$. Measurement uncertainty was $0.61 \%$, which is a combined uncertainty at the probability level of $U=95 \%$ for the distribution coefficient $k=2$. Freezing points are expressed in degree Celsius nebo ${ }^{\circ} \mathrm{C}$.

The results of examination were statistically analysed by Unistat software, version 5.1 (Unistat Ltd., 1998) and the impact of milk heat treatment on its FP was assessed.

The significance of FP differences at various heat treatment levels was assessed using paired $t$-test.

\section{Results and Discussion}

Freezing point of heat-treated cow milk

The average FP value of raw cow milk over the whole monitored period was $-0.5252 \pm$ $0.0141{ }^{\circ} \mathrm{C}$.

With heating to the temperature of $72{ }^{\circ} \mathrm{C}$ for $20 \mathrm{~s}$ (A), there was an FP increase in the average value of $-0.5229 \pm 0.0139{ }^{\circ} \mathrm{C}$ which means that there was an average increase of $0.0023{ }^{\circ} \mathrm{C}(P \leq 0.01)$, (Table 1). After pasteurization at the temperature of $85{ }^{\circ} \mathrm{C}$ for $20 \mathrm{~s}(\mathrm{~B})$, another rise was detected up to the value of $-0.5217 \pm 0.0141{ }^{\circ} \mathrm{C}$. Variance as compared to the FP value in raw milk was $0.0034{ }^{\circ} \mathrm{C}(P \leq 0.01)$. After heating at $95{ }^{\circ} \mathrm{C}$ for $20 \mathrm{~s}(\mathrm{C})$, the FP value of $-0.5200 \pm 0.0144{ }^{\circ} \mathrm{C}$ was found, i.e. an increase by $0.0051{ }^{\circ} \mathrm{C}$ $(P \leq 0.01)$ compared to the FP of raw milk. Comparing the differences between FP values after using the three temperatures and exposition times of heat treatment $(\mathrm{A}: \mathrm{B}, \mathrm{A}: \mathrm{C}, \mathrm{B}: \mathrm{C})$, the differences were highly significant $(P \leq 0.01)$.

When comparing the detected consumer heat-treated cow milk FP with a limit value of $-0.520{ }^{\circ} \mathrm{C}$ stipulated by legislation (Decree 638/2004 Coll.), Navrátilová et al. (2006) found that in pasteurised milk, $64.1 \%$ samples did not meet the FP limit value, and in UHT milk, it was as much as $76 \%$ of samples. 
Table 1. The dynamics of cow milk freezing point variation $\left({ }^{\circ} \mathrm{C}\right)$ as depending on the heat-treatment indicators of milk

\begin{tabular}{|c|c|c|c|c|c|c|c|}
\hline FP & O & A & O-A & B & O-B & C & O-C \\
\hline $\bar{x}$ & -0.5252 & -0.5229 & 0.0023 & -0.5217 & 0.0034 & -0.5200 & 0.0051 \\
\hline SD & 0.0142 & 0.0139 & 0.0009 & 0.0141 & 0.0010 & 0.0144 & 0.0014 \\
\hline $\min$ & -0.461 & -0.460 & 0.001 & -0.459 & 0.002 & -0.454 & 0.003 \\
\hline $\max$ & -0.554 & -0.552 & 0.004 & -0.550 & 0.005 & -0.550 & 0.009 \\
\hline
\end{tabular}

SD - standard deviation, min - minimum value, max - maximum value

$\mathrm{O}$ - raw milk $(\mathrm{O})$

A - pasteurization at $72{ }^{\circ} \mathrm{C}$ for $20 \mathrm{~s}$

B - pasteurization at $85^{\circ} \mathrm{C}$ for $20 \mathrm{~s}$

$\mathrm{C}$ - pasteurization at $95^{\circ} \mathrm{C}$ for $20 \mathrm{~s}$

The freezing point of heat-treated goat milk

The average FP value of raw goat milk over the whole of the monitored period was $-0.5533 \pm 0.0086{ }^{\circ} \mathrm{C}(\mathrm{O})$. After pasteurization at the temperature of $72{ }^{\circ} \mathrm{C}$ for $20 \mathrm{~s}(\mathrm{~A})$, there was an increase in FP to the value of $-0.5504 \pm 0.0084{ }^{\circ} \mathrm{C}$ which makes up for an average change by $0.0028^{\circ} \mathrm{C}(P \leq 0.01)$, (Table 2$)$. After pasteurization at the temperature of $85^{\circ} \mathrm{C}$ for $20 \mathrm{~s}(\mathrm{~B})$, another increase was detected to the value of $-0.5491 \pm 0.0081{ }^{\circ} \mathrm{C}$. The difference was $0.0036{ }^{\circ} \mathrm{C}(P \leq 0.01)$ compared to the $\mathrm{FP}$ of raw milk. After heating at $95{ }^{\circ} \mathrm{C}$ for $20 \mathrm{~s}(\mathrm{C})$, the FP found was $-0.5476 \pm 0.0071{ }^{\circ} \mathrm{C}$, which is an increase by 0.0054 ${ }^{\circ} \mathrm{C}(P \leq 0.01)$ compared to the FP of raw milk. Comparing the differences between the values of $\mathrm{FP}$ after using the three temperature and time variables of heat treatment $(\mathrm{A}: \mathrm{B}$, $\mathrm{A}: \mathrm{C}, \mathrm{B}: \mathrm{C})$, the differences were highly significant $(P \leq 0.01)$.

Table 2. The dynamics of goat milk freezing point variation $\left({ }^{\circ} \mathrm{C}\right)$ as depending on the heat-treatment indicators of milk

\begin{tabular}{|c|c|c|c|c|c|c|c|}
\hline FP & O & A & O-A & B & O-B & C & O-C \\
\hline $\bar{x}$ & -0.5533 & -0.5504 & 0.0028 & -0.5491 & 0.0036 & -0.5476 & 0.0054 \\
\hline SD & 0.0086 & 0.0084 & 0.0016 & 0.0081 & 0.0017 & 0.0071 & 0.0019 \\
\hline $\min$ & -0.544 & -0.543 & -0.001 & -0.541 & -0.001 & -0.540 & -0.003 \\
\hline $\max$ & -0.589 & -0.585 & -0.007 & -0.582 & -0.007 & -0.575 & -0.009 \\
\hline
\end{tabular}

$\mathrm{SD}$ - standard deviation, min - minimum value, max - maximum value

$\mathrm{O}$ - raw milk $(\mathrm{O})$

A - pasteurization at $72^{\circ} \mathrm{C}$ for $20 \mathrm{~s}$

B - pasteurization at $85^{\circ} \mathrm{C}$ for $20 \mathrm{~s}$

$\mathrm{C}$ - pasteurization at $95^{\circ} \mathrm{C}$ for $20 \mathrm{~s}$

When increasing the freezing point, differences were detected between the FP values of cow and goat milk (Fig. 1). When comparing the impact of heating O-A, a difference between the FP change in cow and in goat milk was $0.0005{ }^{\circ} \mathrm{C}$, while the comparison of heating impact in $\mathrm{O}-\mathrm{B}$ resulted in $0.0002^{\circ} \mathrm{C}$ and when comparing the impact of heating in $\mathrm{O}-\mathrm{C}$, the difference was $0.0003^{\circ} \mathrm{C}$. The highest difference in FP changes in goat and cow milk was found when assessing the impact of A heating.

Literature data on the impact of heat treatment of milk FP vary. Our findings of the increase in milk FP by $0.0023{ }^{\circ} \mathrm{C}$ (cow) and $0.0028{ }^{\circ} \mathrm{C}$ (goat) after pasteurization at $72{ }^{\circ} \mathrm{C}$ for $20 \mathrm{~s}$ (A) do not correspond with the findings of Kessler (1984) who states that the FP of cow milk after pasterurization at $74{ }^{\circ} \mathrm{C}$ for $30 \mathrm{~s}$ does not display any change, but pasteurization at $85^{\circ} \mathrm{C}$ for $2.8 \mathrm{~s}$ increases the $\mathrm{FP}$ by $0.002{ }^{\circ} \mathrm{C}$ and pasteurization at $95^{\circ} \mathrm{C}$ for $303 \mathrm{~s}$ raises the $\mathrm{FP}$ by $0.001{ }^{\circ} \mathrm{C}$. However, other authors write that the impact of heating on FP is even more significant and that pasteurization increases milk FP by $0.006-0.009{ }^{\circ} \mathrm{C}$ (Singhal et al. 1997) which corresponds with our finding. Due to pasteurization, there was an increase in the dependence on thermal and temporal variables of heat treatment of FP in 


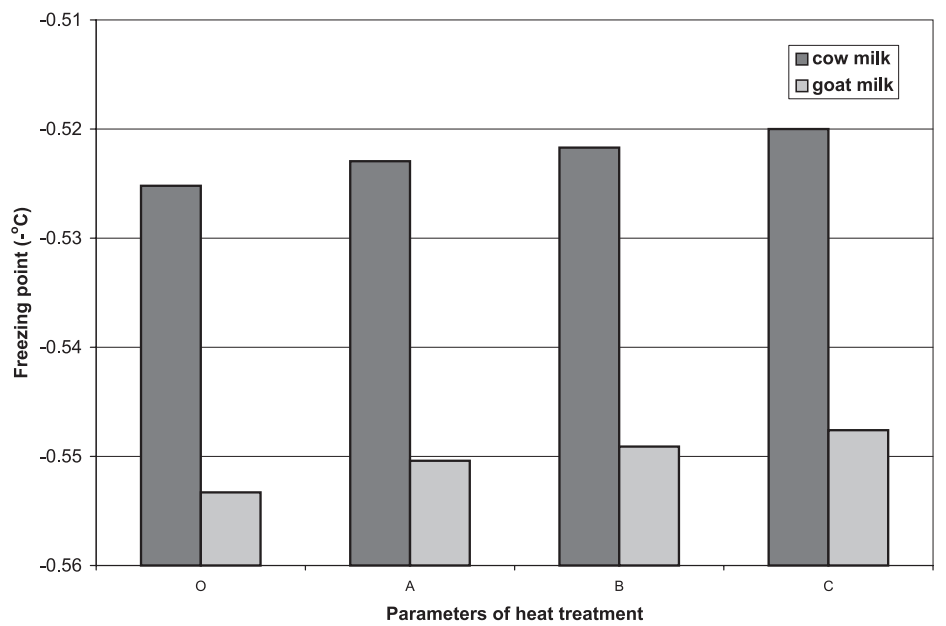

Fig.1. Heat treatment impact on the freezing point values of cow and goat milk

$\mathrm{O}$ - raw milk $(\mathrm{O})$

A - pasteurization at $72{ }^{\circ} \mathrm{C}$ for $20 \mathrm{~s}$

B - pasteurization at $85^{\circ} \mathrm{C}$ for $20 \mathrm{~s}$

$\mathrm{C}$ - pasteurization at $95^{\circ} \mathrm{C}$ for $20 \mathrm{~s}$

cow milk by averages of $0.0023{ }^{\circ} \mathrm{C}(\mathrm{A}), 0.0034{ }^{\circ} \mathrm{C}(\mathrm{B})$ and $0.0051{ }^{\circ} \mathrm{C}(\mathrm{C})$ and in goat milk by averages of $0.0028^{\circ} \mathrm{C}(\mathrm{A}), 0.0036{ }^{\circ} \mathrm{C}(\mathrm{B})$ and $0.0054^{\circ} \mathrm{C}(\mathrm{C})$. Also Rohm et al. (1991) have found a shift of about $0.002{ }^{\circ} \mathrm{C}$ depending on the temperature and time of heating and ascribe the increase in milk FP to the change inside the calcium phosphate complex and pressure change of carbon dioxide.

Literature data on FP changes in goat milk after heat treatment were scarce. Janštová et al. (2007) detected an increase in FP of goat milk after pasteurization at a farm at $72{ }^{\circ} \mathrm{C}$ for $20 \mathrm{~s}$ at a level of $0.0025^{\circ} \mathrm{C}$, which corresponds to our present findings.

The above presented results show that heat treatment impacts the FP of milk significantly depending on the temperature and duration of treatment, and the increase of milk treatment temperature causes its increase (a shift of the values towards zero). According to Pal'o et al. (1992), an increase in FP due to heat treatment is negligible compared to the technological adulteration in primary production and in the dairy.

The dynamics of the FP change in pasteurized goat milk correspond with the dynamics of the changes of pasteurized cow milk. FP values differ from the raw milk FP highly significantly after individual experimental interventions. FP values of heat-treated milk also differ from each other even when comparing individual heat treatments.

If the value of the FP of consumer milk is not monitored by the producer, it is necessary to take this impact into account when establishing the limit value of the FP for the given heat treatment indicators. Monitoring the milk FP values can also bring benefit to the producer with regard to the assessment of the technological yield in cheese production, product drying operations or when making fermented milk products.

\section{Vliv tepelného ošetření na bod mrzutí kravského a kozího mléka}

Cílem práce bylo sledování vlivu ukazatelů tepelného ošetření mléka na změny bodu mrznutí kravského a kozího mléka.

Bod mrznutí (FP) byl stanoven ve 30 bazénových vzorcích kozího a ve 30 bazénových vzorcích kravského mléka $(\mathrm{O})$, které byly podrobeny laboratornímu tepelnému ošetření 
při následujících teplotách: $72{ }^{\circ} \mathrm{C}(\mathrm{A}), 85^{\circ} \mathrm{C}(\mathrm{B}), 95^{\circ} \mathrm{C}(\mathrm{C})$, časová expozice byla u všech tepelných zákroků stejná, a to $20 \mathrm{~s}$.

Bod mrznutí syrového a tepelně ošetřeného mléka byl měřen v souladu s ČSN 570538 termistorovým kryoskopem. FP syrového kravského mléka se tepelným ošetřením zvýšil z původní hodnoty $-0.5252 \pm 0.0114{ }^{\circ} \mathrm{C}$ o $0.0023{ }^{\circ} \mathrm{C}(\mathrm{A}), 0.0034{ }^{\circ} \mathrm{C}(\mathrm{B})$ a $0.0051{ }^{\circ} \mathrm{C}(\mathrm{C})$. Byly sledovány změny hodnot $\mathrm{FP}$ kozího mléka z původní hodnoty $-0.5530 \pm 0.0086^{\circ} \mathrm{C}$, kdy vlivem pasterace došlo ke zvýšení FP v závislosti na teplotně časovém režimu tepelného ošetření průměrně o $0.0028^{\circ} \mathrm{C}(\mathrm{A}), 0.0036{ }^{\circ} \mathrm{C}(\mathrm{B})$ a $0.0054{ }^{\circ} \mathrm{C}(\mathrm{C})$.

Dynamika změn byla obdobná u kozího a kravského mléka. Hodnoty bodu mrznutí po jednotlivých pokusných zásazích se statisticky významně lišily oproti hodnotě neošetřeného mléka stejně jako hodnoty FP po jednotlivých zásazích vzájemně. Nárůst teploty tepelně ošetřeného mléka kravského i kozího způsobuje vzrůst bodu mrznutí (posun hodnot směrem k nule).

\section{Acknowledgement}

This research was supported by Grant 6215712402 of the Ministry of Education, Youth and Sports of the Czech Republic.

\section{References}

Alichanidis E, Polychroniadou A 1995: Special features of dairy products from ewe and goat milk from the physicochemical and organoleptic point of view. In: Production and utilization of ewe and goat milk. Proceedings of the IDF/ Greek National Committee of IDF/CIRVAL Seminar, Crete, pp. 21-43

Antunac N, Havranek J, Samarija D 2001: Freezing point of goat's milk. Milchwissenschaft 56: 14-16

Bhandari V, Singh H 2003: Physical Methods. In: Roginski H. (eds.): Encyclopedia of Dairy Sciences. FourVolume Set. Academic Press, London, pp. 93-101

Buchberger J 1996: Some notes on milk freezing point. Research on a Cattle Farm, 4: 23-25

Coni E, Di Pasquale M, Fava L, Bocca A 1997: A pilot survey on the freezing point of raw and heat-treated Italian milk. Ital J Food Sci 9: 239-248

CSN 570538 1998: Determination of freezing point in milk - cryoscope method. Czech Standard Institute, Prague, 6 p. (in Czech)

Decree 203/2003 Coll., of the Ministry of Agriculture on veterinary requirements for milk and dairy products. Official journal, 2003, Chapter 73, pp. 3886-3916 (in Czech). In: Navrátilová P, Janštová B, Glossová P, Vorlová L 2006: Freezing point of heat-treated milk in the Czech Republic. Czech J Food Sci 4: 156-163

Decree 638/2004 Coll., of the Ministry of Agriculture on veterinary requirements for egg products, and Decree 638/2004 Coll. on veterinary requirements for milk and dairy products. Official journal, 2004, Chapter 216, 11533-11536 (in Czech). In: Navrátilová P, Janštová B, Glossová P, Vorlová L 2006: Freezing point of heattreated milk in the Czech Republic. Czech J Food Sci 4: 156-163

Espie WE, Mullan WMA 1990: Compositional aspects of goat milk in northern Ireland. Milchwissenschaft 45: 361-362

Fox PF, McSweeney PLH 1998: Dairy Chemistry and Biochemistry. Thomson Science, London, pp. 443-447

Janštová B, Dračková M, Navrátilová P, Hadra L, Vorlová L 2007: Freezing point of raw and heat-treated goat milk. Czech J Anim Sci 52: 394-398

Kessler HG 1984: Effects of the technological processes on the freezing point of milk. Milchwissenschaft 39: 339-341

Navrátilová P, Janštová B, Glossová P, Vorlová L 2006: Freezing point of heat-treated milk in the Czech Republic. Czech J Food Sci 4: 156-163

Pal'o V, Fábry I, Hostin S 1992: Cryoscopic milk quality study. II. Overview of milk freezing points during dairy processing. Pol'nohospodárstvo 38: 11-12 (In Slovak)

Rohm H, Pleschberger C, Foissy H 1991: Der Gefrierpunkt österreichischer Rohmilch. 1. Einflussfaktoren auf den originären Gefrierpunkt. Ernährung 15: 333-337

Singhal RS, Kulkarni PR, Rege DV 1997: Handbook of Indices of Food Quality and Autenticity. Woodhead Publishing Limited, Cambridge England, pp. 168-174

Slaghuis BA 2001: The freezing point of authentic and original farm bulk tank milk in The Netherlands. Int Dairy J 11: 121-126

Szijarto L, Van De Voort FR 1983: Determination of added water and bovine milk to caprine milk. J Dairy Sci 66: $620-623$

Unistat, version 5.11998 (Unistat Ltd.)

Wiedemann M, Buchberger J, Klostermeyer H 1993: Ursache für anomale Gefrierpunkte der Rohmilch. DMZ Lebensmittelindustrie und Milchwirtschaft 114: 634-644

Zee B, Drogt J, Giessen TJJ 1982: The freezing point of authentic farm tank milk in The Netherlands Neth Milk Dairy J 36: 291-303 